\title{
Income inequality, status decline and support for the radical right
}

\author{
Sarah Engler ${ }^{1}$ and David Weisstanner ${ }^{2}$
}

\begin{abstract}
Support for the radical right has risen in most Western democracies. Globalization and modernization processes are usually seen as the source of this development, reshaping political conflicts and producing new groups of people that feel 'left behind'. However, few studies test how the relatively common trends in globalization shape the variation in the timing and extent of radical right support across countries. Focusing on the economic dimension of the 'losers of globalization' theory, we argue that income inequality is a suitable indicator to measure the extent to which some groups have fallen behind and to capture the fear of decline in material well-being of people not (yet) at the bottom of the income distribution. The relative deterioration in material conditions, we argue further, translates into a lower subjective social status of vulnerable groups who then turn towards the radical right. By cultivating nativism and thus providing non-economic criteria of social status, the radical right becomes more attractive as societies become more unequal. We show evidence for our hypothesis by comparing vote shares for radical right parties in 20 Western democracies between 1980 and 2016 . The findings indicate that rising income inequality substantially increases support for the radical right in the long run. In addition, rising inequality translates into lower subjective social status of nontertiary educated men and this process of status decline further contributes to radical right support. Hence, there are both material and non-material linkages between income inequality and radical right support.
\end{abstract}

\section{Introduction}

The political landscape in Europe and other Western democracies is changing. Individualization and increasing electoral volatility pose a challenge for mainstream parties and question their formerly firm positions in politics (Mair 1997; see also Armingeon and Schädel 2015). Furthermore, satisfaction with the workings of democracy and political trust have deteriorated with the Great Recession and its aftermath (Armingeon and Ceka 2014; Armingeon and Guthmann 2014; Armingeon, Guthmann, and Weisstanner 2016). One major symptom of the current crises and transformations facing many old democracies is the rise of radical right parties (RRPs) that started in the late 1980s and has not yet come to an end (Kriesi and Pappas 2015).

\footnotetext{
${ }^{1}$ Universität Zürich sarah.engler@zda.uzh.ch

${ }^{2}$ University of Oxford david.weisstanner@spi.ox.ac.uk
}

R. Careja et al. (eds.), The European Social Model under Pressure, https://doi.org/10.1007/978-3-658-27043-8_22 
The most prominent explanation of radical right support focuses on structural transformations associated with globalization and modernization. By altering economic, political and cultural conditions, these transformations produce an electoral demand among the 'losers of globalization' for the new radical right that opposes these changes (Kitschelt 1995; Kriesi et al. 2008; Oesch 2006b). Some argue further that this demand was reinforced by the ideological convergence of mainstream parties, most notably the shift towards more market-oriented policies by the mainstream left during the 1990s (Kitschelt 1995, 2018; Mudde and Rovira Kaltwasser 2018; Karreth, Polk, and Allen 2012). A large body of literature has focused on the implications of the 'losers of globalization' thesis at the individual level by looking at the impact of educational and socioeconomic background, anti-immigration attitudes and political trust on radical right voting (e.g. van der Brug, Fennema, and Tillie 2000, 2005; Bélanger and Aarts 2006; Stubager 2010). However, one of the major difficulties of the structural approach and its empirical tests at the individual-level, is to understand the timing and cross-national variation of radical right support. How can we explain the early rise of the Swiss SVP, the Austrian FPÖ or the Norwegian Progress Party, while in other countries the support for radical right parties was only marginal until very recently? Modernization and globalization affect all Western countries. As a consequence, should these developments not also produce 'losers' that vote for radical right parties in all countries alike?

Beneath the economic interpretation of the 'losers of globalization' thesis lies the implicit assumption that increasing social and economic inequalities between different social groups translate pressures from globalization into individual vote choices. ${ }^{3}$ However, trends in economic inequality have varied considerably between countries and cannot unambiguously be traced back to globalization (OECD 2008, 2011, 2015). Surprisingly few studies operationalize the economic inequalities generated in the wake of expanding globalization and test whether these inequalities feed into the support for radical right parties. Those that exist are usually based on individual-level survey data for a limited time span and fail to encompass the full extent of rising inequality over the past couple of decades. Against this background, we explore the role of changes in income inequality to explain differences in radical right support across 20 Western democracies between 1980 and 2016.

Our theoretical framework is broadly situated in the context of economic grievances and the consequences of 'relative deprivation' on support for radical right parties. If income inequality increases, we expect that voters blame established parties for the relative deterioration in their material conditions and become more likely to support radical right parties. Furthermore, we hypothesize that this effect depends on the type of inequality and might be more pronounced for rising 'market income inequality', because government redistribution can only compensate

\footnotetext{
${ }^{3}$ The 'losers of globalization' literature discusses different consequences of globalization that reshape political conflicts and produce 'winners and losers' alike, but whose effects are difficult to disentangle from each other: increasing economic competition, cultural diversity and political integration (Grande and Kriesi 2012,12). While acknowledging the importance of the cultural and political aspects, it is the economic dimension we focus on in this chapter.
} 
for the relative decline, or stagnation, of market earnings to a limited degree. Losses of relative market income are not only associated with economic insecurity, but also a loss of subjective social status. The decline of subjective status emerges as the crucial link between economic conditions and electoral behaviour (Gidron and Hall 2017a, 2017b). Income inequality captures more than material conditions, and this might explain why political consequences of increasing inequality go beyond the economic divide. Our empirical analysis lends support to our hypotheses and finds a substantial association between long-run changes in market inequality and radical right support. The findings imply that income inequality and other indicators of relative deprivation should be given closer attention to explain the timing in rising support for radical right parties.

\section{Income inequality and the winner-loser narrative of radical right support}

\subsection{Globalization, structural changes and income inequality}

Proponents of the 'losers of globalization' (LoG) thesis start from the observation that globalization is part of a larger set of structural transformations taking place in advanced capitalist democracies. Usually labelled under the umbrella term 'modernization', the transformations on the economic side involve not only the internationalization of production processes but also deindustrialization and technological change (Bornschier 2018). These changes are visible at the occupational level and include the upgrading or downgrading of specific sectors and industries, as the globalized economy alters the skill requirements in the labour market (Oesch 2006a, 2008, 2013, 2015). Exposure to globalization gives rise to a 'new class divide' between low-skilled workers and socio-cultural professionals (Lachat and Dolezal 2008). In essence, the LoG approach argues that these new divisions create a structural demand for radical right parties among 'low-skilled workers who are hurt by economic openness' (Grande and Kriesi 2012, 13).

At the same time, the LoG literature describes the widening of occupational and educational divides as a relatively uniform process across different countries. For example, Bornschier $(2010,27)$ notes that the economic difficulties of low-skilled workers have emerged simultaneously with rising income inequality in many countries. However, the claim that lowskilled workers are generally worse-off from globalization is difficult to reconcile with the large variation in wage gaps between low-educated and high-educated employees across countries and over time (Autor 2014; Hanushek et al. 2015; Weisstanner and Armingeon 2018). The dichotomy between low-skilled and high-skilled occupations also ignores the large variation in earnings developments within occupations, emerging as a crucial driver of overall earnings inequality (van Heuvelen 2018). 
For these reasons, we maintain that income inequality is a more informative indicator of the new economic divides following in the wake of globalization and modernization. In contrast to the low-skilled/high-skilled dichotomy, income inequality can be seen as a continuous measure of the extent that the losers 'fall behind' or the winners 'pull ahead'. Globalization possibly contributes to wage pressure in the lower end of the distribution, but several studies fail to find a clear association between economic globalization and rising income inequality (Bradley et al. 2003; OECD 2011; Huber and Stephens 2014). There has always been variation in inequality to some extent, but since the 1980 s it has increased dramatically in some countries and less in others. Looking at changes in inequality within each country, we can explore in greater detail how economic divides have evolved during the period of globalization.

In sum, the effects of globalization on income inequality are likely to be more varied across countries and more diverse than the proponents of the LoG thesis assume. The different responses of inequality to the structural transformations might be key in understanding why the support of radical right parties varies across countries and over time, despite similar trends of globalization and modernization. This is our motivation to revisit the LoG thesis focusing more explicitly on income inequality. We will discern two types of income inequality. First, 'disposable income inequality', that is the sum of labour market earnings and the compensatory measures of the state. Second, 'market income inequality', where pressures from globalization and modernization operate more directly through market mechanisms. Both have potential impact on the incentives to vote for the radical right, but the incentives are of different nature depending on the type of income inequality.

\subsection{Two types of income inequality and their political consequences}

We first focus on 'disposable income' (post-tax and post-transfer), before moving on to 'market income' (pre-tax and pre-transfer) for the second hypothesis. All previous studies that we are aware of on the link between inequality and radical right support have employed inequality measures based on disposable income (Coffé, Heyndels, and Vermeir 2007; Jesuit, Paradowski, and Mahler 2009; Han 2016; Rooduijn and Burgoon 2017; Burgoon et al. 2018). Disposable income is clearly identifiable as the total means that people have 'in their pockets', independent from whether the sources of income are salaries or state transfers.

Rising inequality of disposable incomes implies a relative deterioration of material conditions for a majority of the population (including the median voter), as the gap to the upper locations in the distribution increases. In a simple class-voting framework, this might be expected to reduce the support for (radical) right parties and boost support for left-wing parties, which would implement redistributive policies to correct rising inequality (Pontusson and Rueda 2010). However, this model has been severely challenged by the literature on party system change including the proponents of the LoG thesis discussed above. Party competition on the cultural dimension and electoral demand on non-economic issues qualify the expectation 
that the losers of rising inequality would automatically seek remedy with left-wing parties. Relatedly, economic policy positions of left-wing parties have shifted significantly to the right over the past decades in many countries (Kitschelt 1994; Karreth, Polk, and Allen 2012). An additional reason that has received less attention is that the main losers from rising inequality also have a higher propensity for non-voting and lower levels of political efficacy (Anderson and Beramendi 2008; Solt 2008; Marx and Nguyen 2018).

A more promising line of argument builds on the framework of retrospective voting and the 'relative deprivation'-theory. Until very recently, radical right parties were usually in the opposition and, by definition, they employ a strong anti-establishment discourse (Mudde 2007). In this line of thought, the relative deterioration of material conditions that rising inequality entails should lead to the punishment of established parties. Resembling a form of pocketbook voting, the deterioration in relative terms will be an undesirable outcome not only for those who are already at the bottom of the distribution, but also for all those who fear income loss.

Previous studies have extensively tested this line of retrospective voting for RRPs using unemployment as the main indicator; the empirical evidence turns out to be quite mixed (Arzheimer 2009; Vlandas and Halikiopoulou 2018). However, inequality seems a far better indicator than unemployment for the concept of 'relative deprivation' (Runciman 1966), which underlies most of the studies that focus on the role of economic grievances on radical right support (Mudde and Rovira Kaltwasser 2018). Unemployment captures only a snapshot of the current situation and disproportionally affects voters at the bottom of the income distribution (Pontusson and Weisstanner 2018). However, individuals can fall behind gradually and for this type of relative losses, income inequality is a far more precise measure. Based on the assumption that relative income loss matters, our first hypothesis states:

H1: Rising disposable income inequality increases the radical right vote share.

Our second measure of income inequality is based on 'market income'. Other than disposable income inequality, market income inequality does not measure the distribution of the actual amount of money people have 'in their pockets', but their (hypothetical) income before any taxes, social security contributions and transfers from and to the government. It is therefore exposed to pressures from global competition and modernization processes more directly than the disposable income inequality. Although it might be a more abstract parameter for individuals, we believe that it plays an important part in explaining variance in radical right support, since changes in market earnings are likely to be closely associated and interpreted in terms of one's subjective status in society.

Several recent studies find that a decline in subjective social and economic status increases an individual's likelihood to vote for the radical right (Gidron and Hall 2017b; Gest, Reny, and Mayer 2017). Gidron and Hall (2017b) explain the rise in radical right support in Europe and the U.S. with the decline in the subjective status of white male without tertiary education over the past two decades. Subjective status is a relative and hierarchical measurement, and it is very 
likely that income inequality and the comparison with others plays an important part in it (Han 2016). We argue that market income, even if it does not entirely mirror the material condition of an individual, is crucial in the perception of the own social status. Wages and salaries earned in the labor market are the primary source of income for most people and determine the lion's share of their consumption possibilities. Non-market sources of income, like welfare state transfers, are unlikely to boost subjective social status to the same extent because their recipients are not always considered as 'deserving' (van Oorschot 2006) and are subject to stigmatization. ${ }^{4}$ In addition, in most welfare regimes, the level of benefits is a function of the (past) level of market earnings. Consequently, rising market income inequality produces a larger group of people that may feel less appreciated in comparison to others, even when the state redistributes income from the top to the bottom. Moreover, similar to the disposable income inequality, high market income inequality deteriorates the potential decline in subjective appreciation and status of those fearing market income losses. In addition, even if redistribution provides a safety net for those affected by a sharp decline in market income, it is unlikely that the welfare state fully eliminates fears of market income loss. Imperfect information on the existence, eligibility and size of welfare services and reluctance to be dependent on state services increase the insecurity about material well-being after a decline in market income (Riphahn 2003).

Radical right parties as opponents to globalization and European integration offer the people negatively affected by higher market inequality a potential alternative to the mainstream parties (Kriesi et al. 2008; Gidron and Hall 2017b). In addition, by politicizing immigration they create a new criterion for social status that is not dependent on the economic status and market income, and that puts immigrants at the bottom of social hierarchy (Gidron and Hall 2017b, 63). We therefore hypothesize that rising market income inequality, mediated by declining perceptions of subjective social status, increases the support for radical right parties to a similar, or even stronger, extent than rising inequality of disposable income.

H2: Rising market income inequality, mediated by perceived subjective status, increases the radical right vote share.

\section{Data and methods}

This chapter relies on a macro-level analysis to explain the variation in the timing and extent of support for radical right parties. Although we can make few, if any, causal claims due to risk of aggregation bias, we see our analysis as a useful complement to recent studies employing more limited time periods. For example, many recent studies based on the European Social Survey start in 2002 and disregard trends in the 1980s and 1990s. In contrast, our time period ranges

\footnotetext{
4 Generous unemployment benefits fail to fully compensate for the negative psychological effects of unemployment on subjective well-being (Wulfgramm 2014; Mousteri, Daly, and Delaney 2018). 
from 1980 to 2016, covering much of the development of rising income inequality and radical right parties in the postwar period. The sample comprises of 20 advanced capitalist democracies and OECD member states. ${ }^{5}$

The dependent variable is the vote share of radical right parties (RRP) in each lower-house election. Political parties that promote a nativist and authoritarian political platform and combine it with a populist discourse dividing the society into 'the corrupt elite' and 'the pure people' are classified as RRP (Mudde 2007, 22-23). Data on the vote share of radical right derives from Armingeon et al. (2018), which includes a category of radical right parties that closely follows Mudde's (2007) definition. ${ }^{6}$ Because of the right-skewed distribution of RRP vote shares, including many zero values, we use the logarithm of the RRP vote share plus one percent.

Our main independent variables are two indicators of income inequality. The first is the Gini coefficient (ranging from 0 to 100) for disposable household income, i.e. the total income including welfare transfers and net of taxes and social security contributions. The second measure is the Gini based on market household income, which only captures earnings from paid employment and capital income before taxation. Our source is the SWIID database (Solt 2016), which has the largest coverage across countries and years. It is based on Luxembourg Income Study (LIS) as the primary source and complements the LIS estimates with other sources. Since the SWIID data covers the whole adult population, its measures for market inequality are inflated in countries with generous public pension systems, where retirees have very little market income (Huber and Stephens 2014, 246). However, this bias is less of an issue for our purposes because we are mainly interested in changes within countries, rather than inequality levels. Having said this, the SWIID data strongly correlate with LIS data covering only working-age households, ${ }^{7}$ and we find substantially the same results based on LIS data.

To test the proposed mediator mechanism about subjective social status, we collected data from the International Social Survey Programme (ISSP) based on a question of whether individuals perceive themselves at the bottom or the top in society on a scale from 0 to 10 . We calculate the average relative subjective status of non-tertiary educated men as a percentage of the average status of all men. Following Gidron and Hall (2017b) we expect their subjective

\footnotetext{
${ }^{5}$ See Figure 1 for the country list. We excluded Eastern European countries due to two reasons. First, the triple transition from communism to market economy, national states and democracy not only increases income inequality, but produces challenges in a variety of areas that are not that easily comparable with the transformations in the old democracies (Offe 1991). Second, not only radical right parties, but also the nationalist communists pursue a political agenda promoting nativism and rejecting supranationalism, therewith providing the 'losers of transition' an alternative to the radical right (Kitschelt 1992). We also excluded Iceland and Luxembourg due to their small population size. Finally, we exclude the United States, where the conflict between populist/radical and established/mainstream right runs through one of the major parties.

${ }^{6}$ Armingeon et al. (2018) deviate from Mudde's original classification of some (borderline) cases, such as the Swiss People's Party (radical right from 1995 on), the Italian National Alliance, as well as the List Pim Fortuyn. In addition, we deviate from Mudde (2007) and Armingeon et al. (2018) by classifying the Norwegian Progress Party as radical right, due to its turn from a pure anti-tax populist platform to an anti-immigrant platform (visible already since the mid-1980s) and following other recent literature (Oesch and Rennwald 2018).

${ }^{7}$ The correlation coefficients are 0.97 for disposable income inequality and 0.90 for market income inequality.
} 
social status to be most affected by increasing inequality. ${ }^{8}$ The data coverage for this variable is quite patchy and missing altogether in four countries, which dramatically reduces our sample size and forces us to limit the statistical analysis to a few preliminary tests. For the descriptive findings involving subjective status, we need to limit the analysis to 14 countries for which we can trace changes in subjective relative status across a long-term time period from the 1990 s/early 2000s until after the financial crisis of 2008-09.

Our control variables are selected on the basis of comparable macro-level analyses of RRP support (e.g. Vlandas and Halikiopoulou 2018). They include unemployment rates, real GDP growth, the generosity of unemployment benefits, the Gallagher index of disproportionality of electoral systems and voter turnout. We further add a dummy for radical left parties in order to control for the possibility that those affected of high income inequality prefer to vote for a radical left party instead (see Rooduijn and Burgoon 2017), since they are also skeptical of global markets and employ anti-establishment rhetoric (March and Rommerskirchen 2015; Marks, Wilson, and Ray 2002). The major difference to the radical right is that they abstain from providing non-economic criteria of social status but focus on redistribution from rich to poor. Apart from unemployment benefit generosity (Scruggs, Jahn, and Kuitto 2014), all control variables come from the Comparative Political Data Set (Armingeon et al. 2018).

\subsection{Estimation strategy}

We investigate the relationship between changes in inequality and RRP votes using time-series cross-sectional (TSCS) analysis. Other than previous studies (e.g. Vlandas and Halikiopoulou 2018), we focus exclusively on trends within countries and therefore estimate regressions with country fixed effects. This arguably is a conservative test, because the unit dummies absorb any differences in independent variables across countries (Plümper, Troeger, and Manow 2005). In other words, we analyze the effects of rising inequality on RRP support without relying on the assumption that only high levels of inequality, in cross-national perspective, should be conducive for rising RRP support.

Furthermore, we go beyond existing studies by distinguishing short-run and long-run effects of inequality. To this end, we estimate an 'autoregressive distributed lag' model (ADL) of the most general form (de Boef and Keele 2008; Beck and Katz 2011):

$$
\mathrm{Y}_{\mathrm{it}}=\alpha_{0}+\alpha_{1} \mathrm{Y}_{\mathrm{it}-1}+\beta_{0} \mathrm{X}_{\mathrm{it}}+\beta_{1} \mathrm{X}_{\mathrm{it}-1}+\varepsilon_{\mathrm{it}}
$$

While the parameter $\beta_{0}$ estimates the short-term effect of our independent variable(s), the dynamic properties of the ADL model allow estimating the cumulative effects of $\mathrm{X}$ in the longrun relationship between $\mathrm{X}$ and $\mathrm{Y}$. Specifically, the total long-run effect (multiplier) is calculated as the sum of $\beta_{0}$ and $\beta_{1}$, divided by 1 minus the coefficient for the lagged dependent

\footnotetext{
${ }^{8}$ The rise in female labor force participation over the past decades makes the same assumption for low-educated women less likely.
} 
variable $\left(\alpha_{1}\right)$. The standard errors for the long-run multiplier are estimated using the Bewley transformation (de Boef and Keele 2008, 191-192.). We estimate the ADL model using ordinary least squares (OLS) and standard errors clustered by country.

\section{Analysis}

Before turning to the regression analysis, Figure 1 presents a descriptive overview of the trends in market inequality and radical right party vote shares between 1980 and 2016 for our sample of 20 OECD countries. Since we are interested in the relationship of changes in inequality and RRP support and not in the comparison of inequality levels between countries, we use countryspecific scales of the $y$-axes to better display the differences over time within a country. Figure 1 reveals a pattern of rising inequality and rising RRP support in many countries. In the majority of countries where RRPs managed to secure a share of parliamentary votes beyond 2 percent, ${ }^{9}$ there is a positive association between inequality and RRP levels. The relationship goes in the opposite direction only in two countries (France, $r=-0.04$, and Netherlands, $r=-0.09$ ). Note the remarkable fit between inequality and RRP trends in countries where RRP support started to rise comparatively early, such as Austria, Belgium, Denmark, Italy or Norway. These are certainly not the countries where inequality increased most, but each of these countries experienced rising income inequality in the 1990s - much more market than disposable inequality - and the (subsequent) rise of RRPs.

\footnotetext{
${ }^{9}$ This is the threshold adopted by Armingeon et al. (2018). In the four countries where RRPs did not exceed the $2 \%$ vote share in elections (Canada, Ireland, New Zealand and Portugal), inequality increases where markedly slower with an average of 0.12 percentage points per year compared to 0.21 points in the remaining sample.
} 

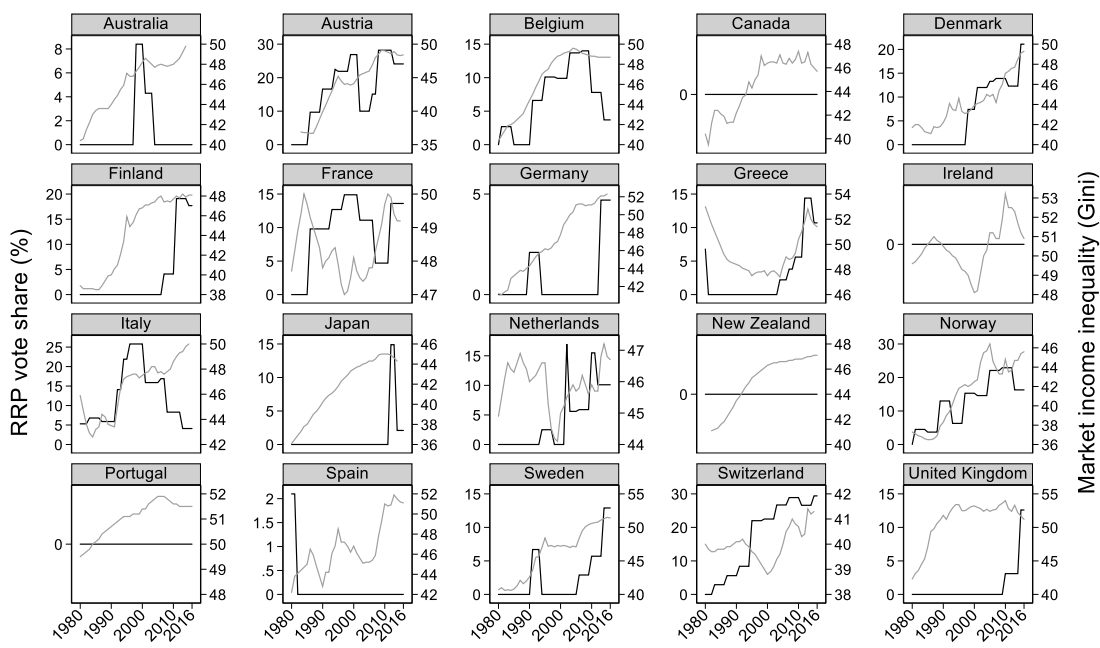

Year

RRP votes

Market inequality

Figure 1: RRP support and market inequality, 1980-2016

Sources: Armingeon et al. (2018), SWIID.

Table 1 reveals the results from autoregressive distributive lag (ADL) regression models, which are a more stringent test of the association between income inequality and RRP vote shares. The models include various combinations of disposable income inequality, market income inequality, redistribution (the relative reduction from market income inequality to disposable income inequality) and subjective status. For these key indicators, we estimate both short-run and long-run parameters. Models 1 and 2 show that both disposable and market income inequality are strongly associated with RRP support within countries in the long-run. The shortrun effect for the contemporaneous period is positive as well, but falls short of attaining statistical significance. The long-run effects of both disposable and market income inequality are robust to several alternative specifications. ${ }^{10}$ Models 3 and 4 also reveal that the strong effects of income inequality (disposable and market) remain robust even after controlling for the impact of redistribution. Compensating higher inequality through taxes and transfers does not moderate the effect of inequality in boosting RRP support. Model 4 indicates that higher redistribution seems to contain RRP support, but the long-run coefficient for redistribution is insignificant in Model 3.

\footnotetext{
${ }^{10}$ The long-run multiplier is statistically significant at least at the 95 percent level when excluding single countries; excluding the five countries with no RRPs; excluding or altering the control variables; using LIS data for the working-age population; or using different time periods (e.g. dropping the 1980s or dropping the 2008-2016 period).
} 
Table 1: autoregressive distributive lag regressions of RRP vote share in 17 OECD countries, 1982-2016

\begin{tabular}{|c|c|c|c|c|c|c|c|}
\hline & 1 & 2 & 3 & 4 & 5 & 6 & 7 \\
\hline Log RRP vote share $t-1$ & $\begin{array}{l}0.58 * * * \\
(0.11)\end{array}$ & $\begin{array}{l}0.54 * * * \\
(0.11)\end{array}$ & $\begin{array}{l}0.57 * * * \\
(0.11)\end{array}$ & $\begin{array}{l}0.54 * * * \\
(0.11)\end{array}$ & $\begin{array}{l}0.54 * * * \\
(0.10)\end{array}$ & $\begin{array}{l}0.33 * * \\
(0.14)\end{array}$ & $\begin{array}{l}0.33 * * \\
(0.14)\end{array}$ \\
\hline $\begin{array}{l}\text { Gini disposable income } \\
\text { (short-run effect) }\end{array}$ & $\begin{array}{c}0.13 \\
(0.09)\end{array}$ & & $\begin{array}{c}0.14 \\
(0.10)\end{array}$ & & $\begin{array}{c}0.04 \\
(0.10)\end{array}$ & & \\
\hline $\begin{array}{l}\text { Gini disposable income } \\
\text { (long-run multiplier) }\end{array}$ & $\begin{array}{l}0.25 * * * \\
(0.05)\end{array}$ & & $\begin{array}{l}0.26 * * * \\
(0.06)\end{array}$ & & $\begin{array}{c}0.06 \\
(0.10)\end{array}$ & & \\
\hline $\begin{array}{l}\text { Gini market income } \\
\text { (short-run effect) }\end{array}$ & & $\begin{array}{c}0.09 \\
(0.06)\end{array}$ & & $\begin{array}{c}0.10 \\
(0.06)\end{array}$ & $\begin{array}{c}0.07 \\
(0.05)\end{array}$ & & $\begin{array}{c}0.03 \\
(0.05)\end{array}$ \\
\hline $\begin{array}{l}\text { Gini market income } \\
\text { (long-run multiplier) }\end{array}$ & & $\begin{array}{l}0.15 * * * \\
(0.03)\end{array}$ & & $\begin{array}{l}0.18^{* * *} \\
(0.03)\end{array}$ & $\begin{array}{l}0.13^{* *} \\
(0.06)\end{array}$ & & $\begin{array}{c}0.04 \\
(0.06)\end{array}$ \\
\hline $\begin{array}{l}\text { Redistribution } \\
\text { (short-run effect) }\end{array}$ & & & $\begin{array}{c}0.01 \\
(0.02)\end{array}$ & $\begin{array}{l}-0.01 \\
(0.02)\end{array}$ & & & \\
\hline $\begin{array}{l}\text { Redistribution } \\
\quad \text { (long-run multiplier) }\end{array}$ & & & $\begin{array}{c}0.00 \\
(0.02)\end{array}$ & $\begin{array}{l}-0.04 * * \\
(0.02)\end{array}$ & & & \\
\hline $\begin{array}{l}\text { Subjective relative status } \\
\text { (short-run effect) }\end{array}$ & & & & & & $\begin{array}{l}-0.04 \\
(0.04)\end{array}$ & $\begin{array}{l}-0.03 \\
(0.03)\end{array}$ \\
\hline $\begin{array}{l}\text { Subjective relative status } \\
\text { (long-run multiplier) }\end{array}$ & & & & & & $\begin{array}{l}-0.11 * * \\
(0.04)\end{array}$ & $\begin{array}{l}-0.08 * * * \\
(0.02)\end{array}$ \\
\hline Unemployment rate & $\begin{array}{l}-0.02 \\
(0.03)\end{array}$ & $\begin{array}{l}-0.03 \\
(0.04)\end{array}$ & $\begin{array}{l}-0.02 \\
(0.03)\end{array}$ & $\begin{array}{l}-0.03 \\
(0.04)\end{array}$ & $\begin{array}{l}-0.03 \\
(0.04)\end{array}$ & $\begin{array}{l}-0.02 \\
(0.04)\end{array}$ & $\begin{array}{l}-0.03 \\
(0.05)\end{array}$ \\
\hline Real GDP growth & $\begin{array}{l}-0.02 \\
(0.02)\end{array}$ & $\begin{array}{l}-0.01 \\
(0.02)\end{array}$ & $\begin{array}{l}-0.02 \\
(0.02)\end{array}$ & $\begin{array}{l}-0.01 \\
(0.02)\end{array}$ & $\begin{array}{l}-0.01 \\
(0.02)\end{array}$ & $\begin{array}{c}0.04 \\
(0.03)\end{array}$ & $\begin{array}{c}0.05 \\
(0.04) \\
\end{array}$ \\
\hline $\begin{array}{l}\text { Unemployment benefit } \\
\text { replacement rate }\end{array}$ & $\begin{array}{c}0.03 \\
(0.08)\end{array}$ & $\begin{array}{l}-0.01 \\
(0.07)\end{array}$ & $\begin{array}{c}0.03 \\
(0.08)\end{array}$ & $\begin{array}{c}0.01 \\
(0.07)\end{array}$ & $\begin{array}{c}0.00 \\
(0.08)\end{array}$ & $\begin{array}{l}-0.11 \\
(0.13)\end{array}$ & $\begin{array}{l}-0.07 \\
(0.14)\end{array}$ \\
\hline $\begin{array}{l}\text { Gallagher index of } \\
\text { disproportionality }\end{array}$ & $\begin{array}{c}0.03 \\
(0.02)\end{array}$ & $\begin{array}{c}0.02 \\
(0.02)\end{array}$ & $\begin{array}{c}0.03 \\
(0.02)\end{array}$ & $\begin{array}{c}0.03 \\
(0.02)\end{array}$ & $\begin{array}{c}0.02 \\
(0.02)\end{array}$ & $\begin{array}{c}0.05 \\
(0.09)\end{array}$ & $\begin{array}{c}0.04 \\
(0.09)\end{array}$ \\
\hline Voter turnout & $\begin{array}{c}0.00 \\
(0.01)\end{array}$ & $\begin{array}{c}0.00 \\
(0.01)\end{array}$ & $\begin{array}{c}0.00 \\
(0.01)\end{array}$ & $\begin{array}{c}0.00 \\
(0.01)\end{array}$ & $\begin{array}{c}0.00 \\
(0.01)\end{array}$ & $\begin{array}{c}0.01 \\
(0.01)\end{array}$ & $\begin{array}{c}0.02 \\
(0.02)\end{array}$ \\
\hline $\begin{array}{l}\text { Radical left party } \\
\text { (dummy) }\end{array}$ & $\begin{array}{c}0.12 \\
(0.17)\end{array}$ & $\begin{array}{c}0.09 \\
(0.21)\end{array}$ & $\begin{array}{c}0.13 \\
(0.18)\end{array}$ & $\begin{array}{c}0.10 \\
(0.20)\end{array}$ & $\begin{array}{c}0.10 \\
(0.23)\end{array}$ & $\begin{array}{c}-0.86^{* * * *} \\
(0.27)\end{array}$ & $\begin{array}{l}-0.79 * * \\
(0.30)\end{array}$ \\
\hline $\mathbf{R}^{2}$ within & 0.42 & 0.42 & 0.42 & 0.43 & 0.42 & 0.29 & 0.29 \\
\hline $\mathbf{N}$ [countries] & $187[20]$ & $187[20]$ & $187[20]$ & $187[20]$ & $187[20]$ & $65[16]$ & $65[16]$ \\
\hline
\end{tabular}

$* p<0.1 ; * * p<0.05 ; * * * p<0.01$. Fixed-effects autoregressive distributive lag regressions (country fixed effects and constant not shown) with robust standard errors clustered by country (in parentheses). The units of analysis are election years.

In line with our hypotheses, the findings so far imply that both disposable and market income inequality are good predictors of RRP vote shares in the long run. ${ }^{11}$ By including both indicators simultaneously, Model 5 shows that the long-run coefficient for market income inequality remains statistically significant, while the effect of disposable income inequality disappears.

\footnotetext{
${ }^{11}$ It should be noted that the effects of inequality primarily pertain in the long-run. This is not surprising in view of the argument that parties' electoral success cannot be measured without idiosyncrasies across single elections or very short time periods (Kitschelt 2018, 169). Most of our models find that slightly more than half of the inequality effect occurs immediately in the first election, while the rest of the effect is distributed across subsequent elections.
} 
This implies that market income inequality trumps the impact of disposable income inequality. Moreover, these models provide little evidence that higher market inequality influences RRP votes because people fear inadequate or declining redistribution. The effect of market inequality remains just as strong once we control for disposable income inequality or redistribution. However, this does not preclude that both disposable and market inequality may have important consequences on citizens' electoral behaviour. After all, the two indicators correlate highly $(r=0.56)$, because market incomes typically make up the lion's share of disposable income. Exploring the possible causal mechanisms below, however, we provide more evidence that it is indeed the evolution of market incomes that is decisive for how people form subjective judgements about their relative position.

The final models in Table 1 test our measure for the subjective perception of relative status. This ISSP-based indicator leads to a drastic reduction in the number of observations and time periods covered, which might explain the unexpectedly strong effect of the radical left party dummy in these models. The main result in Model 6 shows that, in the long-run, lower status perceptions of non-tertiary educated men (relative to overall status perception levels) increase the vote share of RRPs. However, this effect is highly sensitive to country outliers. It only remains statistically significant at the 90 percent level when excluding Denmark and misses conventional levels of significance when excluding Germany or Switzerland. Despite the sensitivity of the results, Model 7 finds that the effect of subjective status perceptions remains significant when we control for market income inequality. These findings not only lend support for a long-run association between subjective status and RRP support, as shown in Figure 2, but also suggest that subjective status perceptions indeed mediate part of the effect of inequality on RRP support.

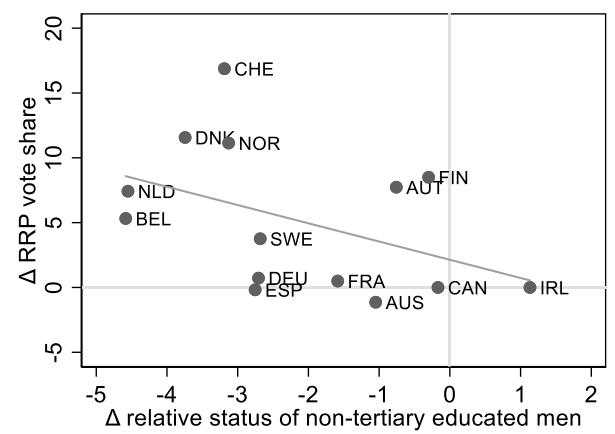

Figure 2: Long-term change in subjective status of non-tertiary educated men and RRP votes

Note: Correlation coefficient $-0.44(\mathrm{~N}=14)$. Long-term change for RRP votes defined as average 2003-2015 minus average 1980-2002; for status defined as average 2012-2015 minus average 1999-2002.

In further support for such a mechanism, Table 2 shows that subjective social status is strongly related to changes in income inequality over the past decades. These fixed-effects OLS 394 
regressions indicate how both disposable and market income inequality trends within countries are strongly related to trends in subjective relative status of non-tertiary educated men. Their status perceptions decline with rising inequality and are not enhanced by increasing redistribution (Models 3 and 4). Finally, subjective status seems much more clearly aligned with market income inequality than with disposable income inequality (Model 5). Within countries, in 14 of the 16 countries for which we have good status data, there is a negative correlation between market inequality and status of low-educated men (the only exceptions are Belgium and Ireland).

Interestingly, while we can confirm that market income inequality comes with lower subjective status of non-tertiary educated men, we find no evidence that redistribution dampens the decline in subjective status. On the contrary, the more the state redistributes from highincome to low-income groups, the lower do non-tertiary educated men evaluate their social status.

Table 2: Fixed-effects regressions of subjective relative status (average) of low-educated men

\begin{tabular}{lccccc}
\hline & $\mathbf{1}$ & $\mathbf{2}$ & $\mathbf{3}$ & $\mathbf{4}$ & $\mathbf{5}$ \\
\hline Gini disposable income & $-0.58^{* * *}$ & & $-0.58^{* * *}$ & & 0.21 \\
& $(0.13)$ & & $(0.15)$ & & $(0.29)$ \\
\hline Gini market income & & $-0.37^{* * *}$ & & $-0.35^{* * *}$ & $-0.47^{* *}$ \\
& & $(0.08)$ & & $(0.09)$ & $(0.18)$ \\
\hline Redistribution & & $-0.31^{* *}$ & -0.07 & \\
& & & $(0.12)$ & $(0.12)$ & \\
\hline $\mathbf{R}^{2}$ within & 0.13 & 0.19 & 0.18 & 0.19 & 0.19 \\
$\mathbf{N}$ [countries] & $173[16]$ & $173[16]$ & $173[16]$ & $173[16]$ & $173[16]$ \\
\hline
\end{tabular}

$* p<0.1 ; * * p<0.05 ; * * * p<0.01$. Fixed-effects OLS regressions (country fixed effects and constant not shown) with robust standard errors clustered by country (in parentheses). Based on annual data.

To repeat, the findings hint that subjective status and RRP support are indeed related to each other. On the one hand, there is a direct (though not very robust) association between status and RRP votes. On the other hand, there is a strong association between status and market inequality, and the latter is unambiguously related to RRP votes. Coming back to the question about income inequality and RRP support, we could therefore easily conclude that relative income matters for RRP support mainly when it corresponds with the relative appreciation that the market income signals to those at the bottom of the income distribution. Better material conditions thanks to redistribution, on the other hand, can barely prevent an impact of market income inequality on radical right support.

The relationship between market income inequality, status decline and support of RRP, however, is less clear once we look at the long-term evolution of subjective status. There is one striking pattern that challenges the role of social status as mediating factor between market income inequality and RRP vote. 

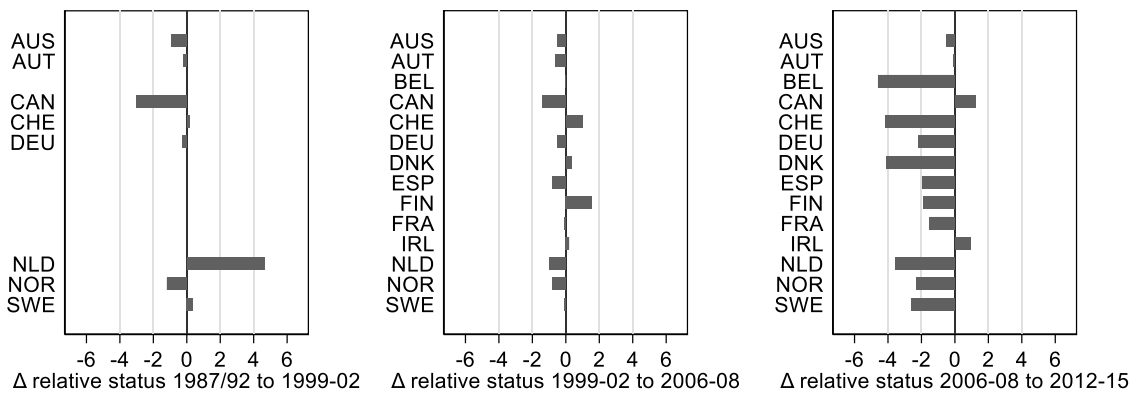

Figure 3: Change in subjective relative status of non-tertiary educated men

Other than market income inequality that is more or less increasing in all countries since the early 1980s (see Figure 1), the subjective status of low-educated men starts to visibly decrease only after the financial crisis in 2008. As Figure 3 illustrates, there is no evidence that the subjective status of low-educated men has been on a long-term decline since the early 1990s. Changes in subjective status during the 1990s and mid-2000s were modest at best. Rising market inequality has therefore clearly predated the fears of status decline. Possibly, the shock of the financial crisis has made rising inequality more visible, upon which the losers have become either more aware or more fearful of status decline. Hence, this mechanism of status decline could explain the recent surge in RRP support. However, rising status anxiety does not seem to explain early support of RRP votes. Early RRP support in Austria, Belgium, Denmark or Italy corresponds with rising market inequality, but not necessarily rising status anxiety. Since data on subjective status is patchy, we have to be careful in drawing final conclusions.

Much speaks in favour that the increasing gap in labour market earnings is more important in explaining RRP support than the increasing gap in actual incomes that people have in their pockets. Material conditions can therefore not fully explain the increase of RRP support. The relationship between market income inequality and declining subjective status perceptions is a first indication that the political consequences of rising inequality go beyond the economic divide. However, we need better data on subjective status and economic conditions at the individual level to test the postulated mechanisms on the complex interplay of market income inequality, status decline and RRP vote over time.

\section{Conclusion}

In this study, we tested whether rising income inequality can explain the variation in radical right support. Inequality is at the core of the economic interpretation of the 'losers of globalization' theory, which postulates that globalization and modernization processes have produced economic and social disadvantages for certain groups in society more than for others. 
However, the LoG literature has not yet been able to explain why similar trends in globalization led to different political outcomes across time and space. One reason might be that globalization has produced different outcomes with regard to income inequality, whether disposable income inequality or market income inequality. Building on the theory of 'relative deprivation', we expected that a relative deterioration of material conditions of a large group of people increases the support for radical right parties. Compared to unemployment, whose effect on radical right vote has already been tested in several studies, we perceive income inequality as a better indicator to account for economic grievance and relative deprivation, because it reflects the extent to which citizens fall behind or stagnate even if they retain their job. We tested this claim using data on income inequality and radical right support for 20 advanced capitalist democracies and found that, independent of the type of income inequality, a rise in income inequality indeed leads to rising vote shares of radical right parties.

By directly measuring inequality, we go one step further than the LoG literature, which does not offer clear measures of socio-economic gaps between groups and their evolution over time across different countries. The paper therefore contributes to the literature on radical right vote by refining the causal chain between structural economic changes and political behaviour. Furthermore, we propose subjective status perception as a key mediating link between economic conditions and radical right vote. Although our evidence is somewhat mixed, we found hints that subjective social status reflects underlying trends of market inequality. The fact that market income inequality remains an important determinant even when controlling for redistribution shows that material conditions themselves are not sufficient in explaining radical right support. Rather, market income signals appreciation on the labour market that translates into and gets interpreted in terms of social status. Thus, a decline in social status makes radical right parties, which use alternative non-economic criteria in their claim to restore status, appealing for voters.

The current transformations in Western politics cannot be understood without taking into consideration the dynamics of inequality. In this regard, the findings of this study connect to recent work by Klaus Armingeon on the political causes and consequences of inequality (Armingeon and Schädel 2015; Weisstanner and Armingeon 2018). These studies not only illustrate how inequality tends to reinforce social gaps between advantaged and disadvantaged citizens. They also suggest that the disruptions caused by economic inequality are ultimately based on political choices and can be addressed by appropriate policies and institutions. Whether these policies can stop the flow to the radical right of voters fearing and experiencing status decline is another empirical question. 


\section{References}

Anderson, Christopher J., and Pablo Beramendi. 2008. "Income Inequality and Electoral Participation." In Democracy, Inequality, and Representation. A Comparative Perspective, edited by Christopher J. Anderson and Pablo Beramendi. New York: Russel Sage.

Armingeon, Klaus, and Besir Ceka. 2014. "The Loss of Trust in the European Union during the Great Recession since 2007: The Role of Heuristics form the National Political System.” European Union Politics 15 (1): 82 107.

Armingeon, Klaus, and Kai Guthmann. 2014. "Democracy in Crisis? The Declining Support for National Democracy in European Countries, 2007-2011." European Journal of Political Research 53 (3): 423-42.

Armingeon, Klaus, Kai Guthmann, and David Weisstanner. 2016. "How the Euro Divides the Union: The Effect of Economic Adjustment on Support for Democracy in Europe.” Socio-Economic Review 14 (1): 1-26.

Armingeon, Klaus, and Lisa Schädel. 2015. "Social Inequality in Political Participation: The Dark Sides of Individualisation." West European Politics 38 (1): 1-27.

Armingeon, Klaus, Virginia Wenger, Fiona Wiedemeier, Christian Isler, Laura Knöpfel, David Weisstanner, and Sarah Engler. 2018. Comparative Political Data Set 1960-2016. Bern: Institute of Political Science, University of Bern.

Arzheimer, Kai. 2009. "Contextual Factors and the Extreme Right Vote in Western Europe, 1980-2002." American Journal of Political Science 53 (2): 259-75.

Autor, David H. 2014. "Skills, Education, and the Rise of Earnings Inequality Among the 'Other 99 Percent'." Science 344 (6186): 843-51.

Beck, Nathaniel, and Jonathan N. Katz. 2011. "Modeling Dynamics in Time-Series-Cross-Section Political Economy Data." Annual Review of Political Science 14 (1): 331-52.

Bélanger, Eric, and Kees Aarts. 2006. "Explaining the Rise of the LPF: Issues, Discontent, and the 2002 Dutch Election." Acta Politica 41 (1): 4-20.

Bornschier, Simon. 2010. Cleavage Politics and the Populist Right: The New Cultural Conflict in Western Europe. Philadelphia: Temple University Press.

Bornschier, Simon. 2018. "Globalization, Cleavages, and the Radical Right." In The Oxford Handbook of the Radical Right, edited by Jens Rydgren, 212-38. Oxford: Oxford University Press.

Bradley, David, Evelyne Huber, Stephanie Moller, François Nielsen, and John D. Stephens. 2003. "Distribution and Redistribution in Postindustrial Democracies." World Politics 55 (2): 193-228.

Burgoon, Brian, Sam van Noort, Matthijs Rooduijn, and Geoffrey Underhill. 2018. "Radical Right Populism and the Role of Positional Deprivation and Inequality." Economic Policy, Forthcoming.

Coffé, Hilde, Bruno Heyndels, and Jan Vermeir. 2007. "Fertile Grounds for Extreme Right-Wing Parties: Explaining the Vlaams Blok's Electoral Success." Electoral Studies 26 (1): 142-55.

De Boef, Suzanna, and Luke Keele. 2008. "Taking Time Seriously.” American Journal of Political Science 52 (1): 184-200.

Gest, Justin, Tyler Reny, and Jeremy Mayer. 2017. "Roots of the Radical Right: Nostalgic Deprivation in the United States and Britain." Comparative Political Studies 51 (13): 1694-1719

Gidron, Noam, and Peter Hall. 2017a. "Populism as a Problem of Social Integration." Paper presented at Annual Meeting of the American Political Science Association, San Francisco, Septemer 1, 2017.

Gidron, Noam, and Peter Hall. 2017b. "The Politics of Social Status: Economic and Cultural Roots of Populist Right.” British Journal of Sociology 68 (1): 57-84.

Grande, Edgar, and Hanspeter Kriesi. 2012. "The Transformative Power of Globalization and the Structure of Political Conflict in Western Europe." In Political Conflict in Western Europe, edited by Hanspeter Kriesi, Edgar Grande, Martin Dolezal, Marc Helbling, Dominic Höglinger, Swen Hutter, and Bruno Wüest, 3-35. Cambridge: Cambridge University Press.

Han, Kyung Joon. 2016. "Income Inequality and Voting for Radical Right-Wing Parties." Electoral Studies 42: 54-64.

Hanushek, Eric A., Guido Schwerdt, Simon Wiederhold, and Ludger Woessmann. 2015. "Returns to Skills Around the World: Evidence from PIAAC." European Economic Review 73 (C): 103-30.

Huber, Evelyne, and John D. Stephens. 2014. "Income Inequality and Redistribution in Post-Industrial Democracies: Demographic, Economic and Political Determinants." Socio-Economic Review 12 (2): 24567.

Jesuit, David K., Piotr R. Paradowski, and Vincent A. Mahler. 2009. "Electoral Support for Extreme Right-Wing Parties: A Sub-National Analysis of Western European Elections.” Electoral Studies 28 (2): 279-90.

Karreth, Johannes, Jonathan Polk, and Christopher S. Allen. 2012. "Catchall or Catch and Release? The Electoral Consequences of Social Democratic Parties' March to the Middle in Western Europe." Comparative Political Studies 46 (7):791- 822. 
Kitschelt, Herbert. 1992. "The Formation of Party Systems in East Central Europe." Politics \& Society 20 (1): 750 .

Kitschelt, Herbert. 1994. The Transformation of European Social Democracy. Cambridge: Cambridge University Press.

Kitschelt, Herbert. 1995. The Radical Right in Western Europe: A Comparative Analysis. Ann Arbor: University of Michigan Press.

Kitschelt, Herbert. 2018. "Party Systems and Radical Right-Wing Parties." In The Oxford Handbook of the Radical Right, edited by Jens Rydgren, 167-199. Oxford: Oxford University Press

Kriesi, Hanspeter, Edgar Grande, Romain Lachat, Martin Dolezal, Simon Bornschier, and Timotheus Frey, eds. 2008. West European Politics in the Age of Globalization. Cambridge: Cambridge University Press.

Kriesi, Hanspeter, and Takis S. Pappas. 2015. European Populism in the Shadow of the Great Recession. Colchester: ECPR Press.

Lachat, Romain, and Martin Dolezal. 2008. "Demand Side: Dealignment and Realignment of the Structural Political Potentials." In West European Politics in the Age of Globalization, edited by Hanspeter Kriesi, Edgar Grande, Romain Lachat, Martin Dolezal, Simon Bornschier, and Timotheus Frey, 237-65. Cambridge: Cambridge University Press.

Mair, Peter. 1997. Party System Change: Approaches and Interpretations. Oxford: Oxford University Press.

March, Luke, and Charlotte Rommerskirchen. 2015. "Out of Left Field? Explaining the Variable Electoral Success of European Radical Left Parties." Party Politics 21 (1): 40-53.

Marks, Gary, Carole J. Wilson, and Leonard Ray. 2002. "National Political Parties and European Integration." American Journal of Political Science 46 (3): 585-94.

Marx, Paul, and Christoph Nguyen. 2018. "Anti-Elite Parties and Political Inequality: How Challenges to the Political Mainstream Reduce Income Gaps in Internal Efficacy.” European Journal of Political Research 57 (4): 919-940

Mousteri, Victoria, Michael Daly, and Liam Delaney. 2018. "The Scarring Effect of Unemployment on Psychological Well-Being across Europe.” Social Science Research 72: 146-69.

Mudde, Cas. 2007. Populist Right Parties in Europe. Cambridge: Cambridge University Press.

Mudde, Cas, and Cristóbal Rovira Kaltwasser. 2018. "Studying Populism in Comparative Perspective: Reflections on the Contemporary and Future Research Agenda." Comparative Political Studies 51 (13): 1667-1693.

OECD. 2011. Divided We Stand. Why Inequality Keeps Rising. Paris: OECD.

Oesch, Daniel. 2006a. "Coming to Grips with a Changing Class Structure. An Analysis of Employment Stratification in Britain, Germany, Sweden and Switzerland." International Sociology 21 (2): 263-88.

Oesch, Daniel. 2006b. Redrawing the Class Map: Stratification and Institutions in Britain, Germany, Sweden and Switzerland. Basingstoke: Palgrave Macmillan.

Oesch, Daniel. 2008. "Explaining Workers' Support for Right-Wing Populist Parties in Western Europe: Evidence from Austria, Belgium, France, Norway, and Switzerland." International Political Science Review 29 (3): 349-73.

Oesch, Daniel. 2013. Occupational Change in Europe. How Technology and Education Transform the Job Structure. Oxford: Oxford University Press.

Oesch, Daniel. 2015. "Occupational Structure and Labor Market Change in Western Europe since 1990." In The Politics of Advanced Capitalism, edited by Pablo Beramendi, Silja Häusermann, Herbert Kitschelt, and Hanspeter Kriesi, 112-32. Cambridge: Cambridge University Press.

Oesch, Daniel, and Line Rennwald. 2018. "Electoral competition in Europe's new tripolar political space: Class voting for the left, centre-right and radical right." European Journal of Political Research 57 (4): 783-807.

Offe, Claus. 1991. "Capitalism by Democratic Design? Democratic Theory Facing the Triple Transition in East Central Europe." Social Research 58 (4): 865-92.

Plümper, Thomas, Vera E. Troeger, and Philip Manow. 2005. "Panel Data Analysis in Comparative Politics: Linking Method to Theory." European Journal of Political Research 44 (2): 327-54.

Pontusson, Jonas, and David Rueda. 2010. "The Politics of Inequality: Voter Mobilization and Left Parties in Advanced Industrial States." Comparative Political Studies 43 (6): 675-705.

Pontusson, Jonas, and David Weisstanner. 2018. "Macroeconomic Conditions, Inequality Shocks and the Politics of Redistribution, 1990-2013." Journal of European Public Policy 25 (1): 31-58.

Riphahn, Regina T. 2003. "Rational Poverty or Poor Rationality? The Take-up of Social Assistance Benefits." Review of Income and Wealth 47 (3): 379-98.

Rooduijn, Matthijs, and Brian Burgoon. 2017. "The Paradox of Well-being: Do Unfavorable Socioeconomic and Sociocultural Contexts Deepen or Dampen Radical Left and Right Voting Among the Less Well-Off?" Comparative Political Studies Online First.

Runciman, Walter G. 1966. Relative Deprivation and Social Justice: A Study of Attitudes to Social Inequality in Twentieth-century England. Berkeley: University of California Press.

Rydgren, Jens, ed. 2018. The Oxford Handbook of the Radical Right. Oxford: Oxford University Press. 
Scruggs, Lyle, Detlef Jahn, and Kati Kuitto. 2014. Comparative Welfare Entitlements Dataset 2. Version 201403: University of Connecticut \& University of Greifswald.

Solt, Frederick. 2008. "Economic Inequality and Democratic Political Engagement." American Journal of Political Science 52 (1): 48-60.

Solt, Frederick. 2016. "The Standardized World Income Inequality Database." Social Science Quarterly 97 (5): $1267-81$.

Stubager, Rune. 2010. "The Development of the Education. Cleavage: Denmark as a Critical Case." West European Politics 33 (3): 505-33.

van der Brug, Wouter, Meindert Fennema, and Jean Tillie. 2000. "Anti-Immigrant Parties in Europe: Ideological or Protest Vote?" European Journal of Political Research 37 (1): 77-102.

van der Brug, Wouter, Meindert Fennema, and Jean Tillie. 2005. "Why Some Anti-Immigrant Parties Fail and Others Succeed: A Two-Step Model of Aggregate Electoral Support." Comparative Political Studies 38 (5): 537-573.

van Heuvelen, Tom. 2018. "Within-Group Earnings Inequality in Cross-National Perspective." European Sociological Review Online First: 1-18.

van Oorschot, Wim. 2006. "Making the Difference in Social Europe: Deservingness Perceptions among Citizens of European Welfare States." Journal of European Social Policy 16 (1): 23-42.

Vlandas, Tim, and Daphne Halikiopoulou. 2018. "Does Unemployment Matter? Economic Insecurity, Labour Market Policies and the Far-right Vote in Europe." European Political Science Online First.

Weisstanner, David, and Klaus Armingeon. 2018. "How Redistributive Policies Reduce Market Inequality: Education Premiums in 22 OECD Countries." Socio-Economic Review Online First. https://doi.org/10.1093/ser/mwy018.

Wulfgramm, Melike. 2014. "Life Satisfaction Effects of Unemployment in Europe: The Moderating Influence of Labour Market Policy." Journal of European Social Policy 24 (3): 258-72. 